\title{
DOE/PC/ $90052-122$
}

December 10, 1993

Report No. DOE \SR38.S

CONTRACT TITLE AND NUMBER:

Report Period: 11-1-93 to 11-30-93

Steam Pretreatment for Coal Liquefaction

DE-AC22-90PC90052

CONTRACTOR NAME: The city College of CUNY

Office of Research Administration

New York, NY 10031

CONTRACT PERIOD: 26 September 1990 to 25 January 1994

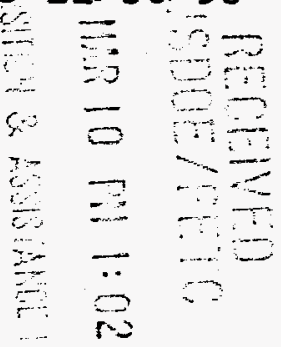

1. CONTRACT OBJECTIVE: No change.

2. TECHNICAL APPROACH CHANGES: No change to technical approach.

3. CONTRACT (BY Reporting Element)

Task 1 - Project Mork Plan. Task complete.

Task 2 - Construction of Liquefaction Test Apparatus.

Task complete.

Tasks 3 - Liquefaction Tests. Work continued using the new lot of Illinois No. 6 coal (CFI No. 31A, Penn state, DECS 2, Sample 106/256). Two tests were carried out in order to establish the liquefaction behavior under slow heating conditions when this coal is pretreated with steam (runs no. 24 , and 25).

For run no. 24 , the sample was pretreated at $335^{\circ} \mathrm{C}$ and 750 psia. A slow heating liquefaction of this treated sample was carried out with deoxygenated tetralin as solvent. To prevent exposure of the pretreated coal to air, slurry was prepared and loaded into a syringe under inert atmosphere in the same way as for rapid heating liquefaction. The slurry was then injected into the autoclave also using the same procedure as in rapid heating, the difference in this case being that the reactor was at room temperature. After slurry injection, the reactor was heated to $400^{\circ} \mathrm{C}$. This required 35 minutes. The reactor was pressurized with hydrogen to 1500 psia and maintained at this temperature and pressure for 30 minutes. The shut down and analytical procedures were then the same as for rapid heating experiments. Pyridine extraction was carried out with 1.63 grams of the steam treated coal. An extraction yield of $31.2 \%$ wt daf was obtained.

For run no. 25, the coal sample was pretreated at $340^{\circ} \mathrm{C}$ and 750 psia. Slow heating liquefaction was carried following the same procedure as for run no. 24. Pyridine extraction was carried out with 1.40 grams of the steam treated coal. An extraction yield of $32.6 \%$ wt daf was obtained. 
The reaction mixtures was analyzed as described in status Report 15, 9 January 1992. Sample losses in the slurry injection line and due to loading were determined directly and subtracted from the amount charged. The results of runs no. 24 and 25 are shown in Table 1 along with values obtained for the previously used batch of coal. Yields are based on daf raw coal.

\section{Table 1}

\section{Liquefaction of Illinois No. 6 Coal}

Conversion (wt\%) Run No. Comments Total Oils Asph. Preasph. Extraction
$\mathrm{C2}^{\circ}$ raw coal
81.6
37.0
16.9
27.7
18.3

\begin{tabular}{|c|c|c|c|c|c|}
\hline $\begin{array}{l}10^{*} \text { steam treated } \\
\text { coal, slow heat }\end{array}$ & $\begin{array}{l}73.8 \\
\text { ing }\end{array}$ & 35.2 & 14.4 & 24.2 & 35.1 \\
\hline $\begin{array}{l}24 * \text { steam treated } \\
\text { coal, slow heat }\end{array}$ & $\begin{array}{l}84.1 \\
\text { ing }\end{array}$ & 51.9 & 13.6 & 18.6 & 31.2 \\
\hline $\begin{array}{l}25 * * \text { steam treated } \\
\text { coal, slow heat }\end{array}$ & $\begin{array}{l}84.9 \\
\text { ing }\end{array}$ & 55.0 & 15.5 & 14.4 & 32.6 \\
\hline $\begin{array}{l}2^{\circ} \quad \text { raw coal } \\
\text { rapid heating }\end{array}$ & 73.8 & 42.2 & 10.0 & 21.6 & -- \\
\hline $\begin{array}{l}\text { 8* raw coal } \\
\text { rapid heating }\end{array}$ & 80.0 & 48.7 & 16.7 & 14.6 & 20.3 \\
\hline $\begin{array}{l}22^{* *} \text { raw coal } \\
\text { rapid heating }\end{array}$ & 72.3 & 39.2 & 13.2 & 19.9 & 20.9 \\
\hline $\begin{array}{l}6 " \text { steam treated } \\
\text { coal, rapid hea }\end{array}$ & $\begin{aligned} & 85.7 \\
& \text { ting }\end{aligned}$ & 60.1 & 17.2 & 8.4 & 22.3 \\
\hline $\begin{array}{l}12 \text { steam treated } \\
\text { coal, rapid hea }\end{array}$ & $\begin{array}{l}79.3 \\
\text { ting }\end{array}$ & 55.8 & 14.7 & 8.8 & 34.7 \\
\hline $\begin{array}{l}23^{* *} \text { steam treated } \\
\text { coal, rapid hea }\end{array}$ & $\begin{array}{l}88.9 \\
\text { ting }\end{array}$ & 57.8 & 13.7 & 17.5 & 33.1 \\
\hline
\end{tabular}

Table continued next page. 
Table 1 (continued).

Liquefaction of Illinois No. $6 \mathrm{Coal}$

\begin{tabular}{|c|c|c|c|c|c|}
\hline $\begin{array}{l}7^{*} \text { steam treated } \\
\text { coal, rapid } h\end{array}$ & $\begin{array}{r}91.6 \\
\text { eating }\end{array}$ & 56.0 & 14.2 & 21.7 & 35.2 \\
\hline $\begin{array}{l}9^{*} \text { steam treated } \\
\text { coal, rapid } h\end{array}$ & $\begin{array}{r}85.2 \\
\text { leating }\end{array}$ & 47.5 & 17.3 & 20.4 & 38.9 \\
\hline
\end{tabular}

$\begin{array}{llllll}11^{*} \text { steam treated } & 66.3 & 38.6 & 19.8 & 7.9 & 32.4\end{array}$ coal, rapid heating exposed to air

- Sample CFI No.27 A

** Sample CFI No.27 B

** Sample CFI No.31 A

In Runs 7 and 9, tetralin contained dissolved oxygen.

The slow heating liquefaction yields from (runs no. 24 and 25) are different from the yield obtained from the previously used sample (run no.10). The oil yield and total yield are significantly higher while the preasphaltene yield is lower. The evidence obtained so far indicates that the behavior of this new sample is different from the one previously used, and averaging yields from the two samples would not be appropriate.

Task 4 - Pretreatment 8tudies. No work in this Task was planed for this report period.

Task 5 - Model Compound studies. Purification of $\alpha-$ naphthylmethyl phenyl ether (1), and $\alpha$-benzylnaphthyl ether (2), has been continued. TLC analysis of the crude product of 1 showed another compound to be present in significant amounts. Recrystallization from ethanol successfully removed a substantial portion of the contaminant. Flash column chromatography (silica), followed by repeated recrystallization was then used to purify the remaining compound. Analysis by NMR spectroscopy showed a purity greater than $98 \%$.

TLC analysis of crude 2 showed the presence of two additional 
major contaminants. An attempt to recrystallize the crude mixture of 2 from ethanol was unsuccessful. To avoid the possibility of acid catalyzed rearrangement of the ether, alumina was then employed as an alternative.

Further purifications are scheduled to be done on both 1 and 2 followed by HPLC and GC analysis.

Task 6 - Reports and Documentation. Monthly status reports are being issued as scheduled.

4. OPEN ITEMS: None

5. SUMMARY STATUS ASSESSMENT AND FORECAST:

Two slow heating liquefaction runs of steam pretreated coal were carried out using the new sample (No.31) of Illinois No.6 coal to check consistency with previous samples. Good agreement was obtained between the runs made with new sample. There were, however, significant differences from yields obtained with the previously used sample. Consequently, averaging yields from the two samples is not appropriate. Further work on this new Illinois No.6 coal sample will be continued next month.

Purification of $\alpha$-naphthylmethyl phenyl ether, and $\alpha-$ benzylnaphthyl ether was continued.

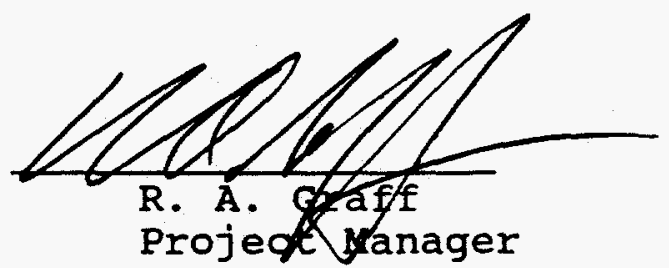

\title{
DISCLAIMER
}

\begin{abstract}
This report was prepared as an account of work sponsored by an agency of the United States Government. Neither the United States Government nor any agency thereof, nor any of their employees, makes any warranty, express or implied, or assumes any legal liability or responsibility for the accuracy, completeness, or usefulness of any information, apparatus, product, or process disclosed, or represents that its use would not infringe privately owned rights. Reference herein to any specific commercial product, process, or service by trade name, trademark, manufacturer, or otherwise does not necessarily constitute or imply its endorsement, recommendation, or favoring by the United States Government or any agency thereof. The views and opinions of authors expressed herein do not necessarily state or reflect those of the United States Government or any agency thereof.
\end{abstract}

